$\underline{\xi}=-m$

\title{
Analgesic activity of the fractions of the aqueous extract of Ximenia Americana (Linné) (Olacaceae)
}

\author{
Tianga Yaya Soro *, Ouga Stanislas Zahoui, Anthelme Semi Nene-Bi, Flavien Traore \\ 22 BP 582 Abidjan 22 Côte D'Ivoire (Ivory Coast), University Felix Houphouët-Boigny, \\ UFR Biosciences, Laboratory of Animal Physiology \\ *Corresponding author E-mail:tiangaso@yahoo.fr
}

\begin{abstract}
This work is the continuation of previous work, during which we investigated the analgesic effects of aqueous extract of Ximenia americana in rats and mice. This work has shown the analgesic action of the aqueous extract of Ximenia americana, effect which seems be due to flavonoids and saponins contained in this total extract. We undertook the fractionation of the crude extract of Ximenia americana, to verify the assumption that the analgesic effect of the aqueous extract from Ximenia americana is due to flavonoids and saponins. To do this we used the fractionation method developed by wagner. This method gave us 6 fractions; we tested on rats and mice. The use of reference molecules such as morphine and phenylbutazone showed the analgesic properties of fractions F2, F4, F6 of the aqueous extract of Ximenia americana.
\end{abstract}

Keywords: Ximenia Americana; Lysine Acetylsalicylate; Analgesic; Saponins.

\section{Introduction}

Ximenia americana (Linnaeus) (Olacaceae) or sea lemon (Kerharo \& Adam 1974), is a shrub highly branched from the base, thorny, glabrous, slender twigs. It sometimes reaches 6 meters high. Its leaves alternate, whole, elliptical, are thin, reaching a length of 4 to $10 \mathrm{~cm}$ and a width of 2 to $4 \mathrm{~cm}$ (Boullard 2001). The flowers consist of axillary cymes. The fruits are drupes globose, fleshy, smooth, yellowish to orange, $3 \mathrm{~cm}$ long, they are edible (Kerharo \& Adam 1974).

Pantropical plant, native from Central and South America, Ximenia americana is widespread throughout tropical Africa. The popular African medicine of tropical areas of Senegal to Zimbabwe, through Nigeria and Tanzania reserve for this plant a considerable place:

The roots, leaves, stem bark; treat various diseases including headaches, stomach, heart, sexual impotence, diarrhea, fever, toothache and mental illness. Previous work has shown the antipyretic.

Previous work has shown the analgesic effect of aqueous extract of Ximenia Americana (Soro et al. 2009). The phytochemical screening of the aqueous extract from Ximenia americana showed the presence of sterols polyterpenes, polyphenols, flavonoids, alkaloids, saponins, and catechin tannin. The analgesic properties of Ximenia americana would be associated with the presence of flavonoids and catechin tannin in the extract. To test this hypothesis, we began the fractionation of the aqueous extract of Ximenia americana and test the analgesic effect of different fractions.

\section{Materials and methods}

\subsection{Material}

\subsubsection{Vegetal material}

It consists of a lyophilized aqueous infusion of stem bark of Ximenia americana (Olacaceae). The stem barks were harvested at Korhogo in northern of Cote d'Ivoire, and identified by the laboratory of Botanical of the Faculty of Biosciences of University Felix HOUPHOUET Boigny Cocody, from a herbarium of the National Centre of Floristic. These barks are dried in the shade between 25 and $28{ }^{\circ} \mathrm{C}$, then ground to a powder from which the aqueous extract was carried out.

\subsubsection{Animal material}

It consists of rats and mice which have been used to study the analgesic activity.

The rats used belong to the species Rattus norvegicus. They are of Wistar strain, and weigh between 150 and $200 \mathrm{~g}$. They were raised to the pet UFR Biosciences of University Felix HOUPHOUET Boigny Cocody, where the average temperature is $28 \pm 3{ }^{\circ} \mathrm{C}$, with a relative humidity of $70 \%$. The photoperiod is from $12 / 24$ hours. The animals received food and water ad libitum.

Mice are of the Mus musculus specie, and of the Swiss strain.

Their weight is between 20 and $30 \mathrm{~g}$.

They are raised in the same way that rats.

\subsubsection{Chemical product}

- $\quad$ Phenylbutazone SIGMA-ALDRICH (France);

- Morphine sulfate: SANOFI-AVENTIS (France)

- Acetic acid: Merck (Germany);

- Formaldehyde: MERCK (Germany). 


\subsection{Methodology}

\subsubsection{Preparation of the aqueous extract of the stem bark of Ximenia Americana}

One hundred and fifty (150) grams of the powder of Ximenia americana stem bark are taken and placed in a beaker of 5 liters. There was added 3 liters of distilled water heated to $100^{\circ} \mathrm{C}$. This mixture is stirred for 24 hours with a magnetic stirrer.

The solution is then filtered on the hydrophilic cotton and paper Wattman $(3 \mathrm{~mm})$. The resulting filtrate was freeze-dried using a freeze dryer (SERIAL type). The lyophilisate is a light-brown powder from $17.50 \%$ yield.

\subsubsection{Fractionation method of the aqueous extract of bark stem of Ximenia Americana}

This fractionation method developed by Wagner (1983) and used by Zirihi (2006), separates the main chemicals substances in the crude extract according to their properties.

Two hundred (200) grams of lyophilisate is dissolved in one liter of $70 \%$ ethanol. The mixture was stirred for 6 hours and decanted into a flask to decant for 24 hours, two phases are obtained:

- Ethanolic phase (F1) which is the supernatant. It contains molecules of low molecular weight (terpenes, oils, alkaloids, flavonoids, cardiac glycosides and the saponins of small size);

- An aqueous phase (F2), which is deposited. It contains molecules of large molecular weight (glucosides, polysaccharides, proteins, glycoproteins, and the Big saponins) (Zirihi 2006).

These two phases were collected separately. They are then evaporated using a rotary evaporator (type RCT basic Labortecknik KIKA). The pellets obtained were dried in an oven at $50{ }^{\circ} \mathrm{C}$. Part of the ethanolic phase is taken up by a mixture of cyclohexane - water $(\mathrm{v} / \mathrm{v})$. The resulting solution was stirred for 6 hours to fully homogenize. It is then decanted for 24 hours in a flask to decant.

Two phases are again obtained:

- A cyclohexane phase (F3) which is the supernatant it contains oils and terpenes;

- An aqueous phase (F4), which settles to the bottom of the tank. It contains alkaloids, saponins, flavonoids, and cardiac glycosides (Wagner 1983).

The two phases are collected separately, evaporated in a rotary evaporator. The pellets obtained were dried in an oven at $50^{\circ} \mathrm{C}$ Portions of the aqueous phase, the pellet is taken up by a mixture of ethyl acetate - water ( $\mathrm{v} / \mathrm{v})$. The solution suffered the same treatment as other mixtures.

Two phases are also collected:

- A supernatant which is the ethyl acetate phase (F5) contains alkaloids and small size flavonoids;

- A pellet which is the aqueous phase (F6) contains saponins, flavonoids of large molecular weight, and cardiac glycosides (Wagner 1983).

The two phases are collected separately and evaporated in a rotary evaporator. The pellets were dried in an oven at $50{ }^{\circ} \mathrm{C}$.

At the end of these operations, six different fractions of the aqueous extract of the stem bark of Ximenia americana are obtained, that are F1, F2, F3, F4, F5 and F6.

\subsubsection{Methods of study of the analgesic activity}

The analgesic activity will be investigated according to its peripheral and central components.

\subsubsection{The writhing test}

The method used is similar to that described by Koster et al (Koster et al. 1959) and modified by Collier et al. (Collier et al 1968).
Intraperitoneal injection of acetic acid in mice causes a painful syndrome, which can be reduced or abolished by the analgesic substances.

The mice were divided into groups of 6 vigils mice. In each lot there are as many males than females. The plant extract, morphine and phenylbutazone are diluted in an isotonic solution of $\mathrm{NaCl} 9$ $\%$. They are injected intraperitoneally to mice $30 \mathrm{~min}$ before the injection of acetic acid at $0.1 \mathrm{ml} / 10 \mathrm{~g}$ body weight (BW).

A set of 6 mice receiving saline, discussed in parallel versus control. The $1.2 \%$ acetic acid is then injected intraperitoneally at the rate of $0.15 \mathrm{ml}$ per $20 \mathrm{~g}$ body weight. Ten minutes after injection of acetic acid, the pain syndrome is characterized by stretching movements of the hind legs and twisting of the dorso-abdominal musculature. Ten minutes after injection of acetic acid, these twists are recorded during a 10 minute time period.

\subsubsection{Tail-flick test}

The method described by d'Amour and Smith (1941) and modified by Gray et al. (1970) is used.

The focusing a light beam heating on the tail of a rat, causes the displacement there of by the rat in less than 6 seconds. The central analgesic substances increase this time.

The rats were divided into groups of 6 vigils rats, each batch contains female rats. The aqueous extract from Ximenia americana, and morphine are diluted in an isotonic solution of $\mathrm{NaCl} 9 \%$. They are injected intraperitoneally 30 minutes prior to irradiation of the tail at a rat of $1 \mathrm{ml} / 100 \mathrm{~g}$ body weight. A set of 6 rats receiving saline discussed in parallel as the control. The experimental device used to generate heat is the Tail-flick (7360, Ugo Basile, Comerio, Italy) which is a device consisting of a light bulb that emits radiant heat for 55 to $60{ }^{\circ} \mathrm{C}$, stopwatch which is triggered together with the radiant heat source and a photocell that automatically stops the timer as soon as the animal withdraws its tail. At the beginning of each trial, the rat was immobilized in a Plexiglas cage; the tail of the animal is positioned at the midlength of the light path, and is based on the photoelectric located on the same route orifice. The counting of the withdrawal latency of the tail and the radiant heat emission are simultaneously triggered. The emission of heat and timer are automatically stopped when the tail undergoes a sudden deflection to turn off the heat light path.

For the determination of nociceptive thresholds, three tests are successively performed at 15 minutes intervals within each trial, three measurements are made at one-minute intervals. The first measure ( 9 seconds maximum) serves as a measure of habituation. The average over the last measures of the three other tests used to determine the nociceptive threshold. The distance tail-lamp and intensity of irradiation are adjusted to obtain the withdrawal of the queue for a period of between 4 and 6 seconds in controls testing before injection of the substance under investigation. After administration of the product, the maximum irradiation time will be 12 seconds to prevent burning of the tail, making random subsequent tests.

\subsubsection{Formaldehyde test}

The method used is the same as that described by Dubuisson and Dennis (1977) and modified by Tjolsen et al. (1992).

The injection of formaldehyde in the foot pad of the right hind paw of the rat causes a painful syndrome, which can be reduced or abolished by the analgesic substances.

The rats were divided into groups of 6 conscious rats. In each lot there are as many males than females. The plant extract, morphine and phenylbutazone are diluted in an isotonic solution of $\mathrm{NaCl}$ at $9 \%$. They are injected intraperitoneally to the rats $30 \mathrm{~min}$ before the injection of formaldehyde at a rat of $1 \mathrm{ml} / 100 \mathrm{~g}$ body weight. A set of 6 rats receiving saline discussed in parallel as the control. 30 minutes after this treatment, $50 \mu \mathrm{l}$ of $2.5 \%$ formaldehyde solution, is injected in the footpad of the right hind paw of rats then the rats are placed under observation for 1 hour. The classification of the pain response is based on the following scale: 
0: rats walk or rely strongly on the treated leg and feel no pain;

1: the treated leg is partially lifted;

2: the treated leg is frankly lifted and seems painful;

3: the rat licks, chews or agitated leg treated and seems to havebadly.

The animals are placed in an enclosure which allows to observe the treated leg, the antinociceptive effect is determined in two phases. The first phase from 0 to 5 minutes, and the second from 15 to 30 minutes with an intervening period of 10 minutes.

\subsection{Statistical analysis}

Statistical analysis was performed using GraphPad Prism 4.0 software (San Diego, Mo, Ca, USA). The comparing of averages of the measurements between batches was made using the Student $\mathrm{t}$ test $(\mathrm{p}<0.05)$.

\section{Results}

\subsection{The Writhing test}

$\mathbf{A}$

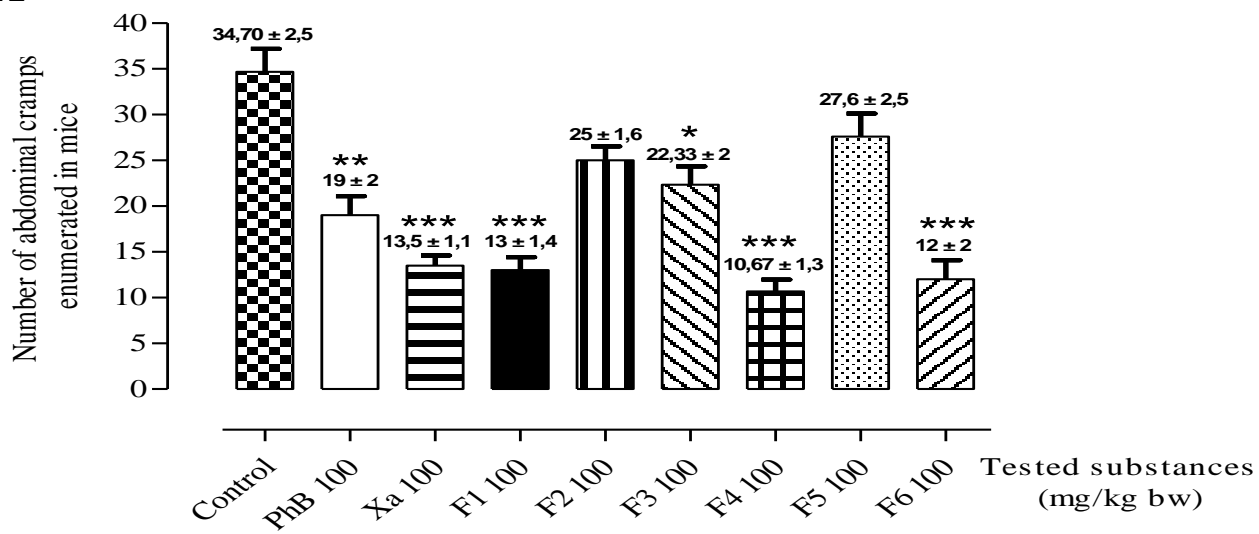

$\mathbf{B}$



Fig. 1:Comparative Study of the Effects of Phenylbutazone, Aqueous Extract of Ximenia Americana and Its Fractions on the Number of Abdominal Cramps Induced in Mice.

A: Number of abdominal cramps after injection of acetic acid in the absence and presence of phenylbutazone, aqueous extract of Ximenia americana, and its various fractions.

Ximenia americana has an inhibitory effect on the cramps greater than that of phenylbutazone. This effect is similar to that of fractions F1, F4 and F6

B: Percent Inhibition abdominal cramps enumerated in mice after injection of acetic acid in the presence of phenylbutazone, aqueous extract of Ximenia americana and its fractions.

Ximenia americana and its fractions F1, F4 and F6 have similar inhibition percentages of abdominal cramps.

Values represent the mean $\pm \mathrm{SEM} ; \mathrm{n}=6$ for each group $* \mathrm{p}<0.05 ; * * \mathrm{p}<0.01 ; * * * \mathrm{p}<0.001$ compared to the control group. 


\subsection{Tail-flick test}

The effects of aqueous extract of Ximenia americana, and morphine on the withdrawal latency of the tail of the rat of the heating light beam, are shown in Table 1. The latency time of the withdrawal of the tail of the control ratsof the light beam is equal to $5.94 \pm 0.54 \mathrm{~s}$.

In the presence of $100 \mathrm{mg} / \mathrm{kg}$ bw of the aqueous extract of Ximenia americana, this latency does not vary significantly. By cons for morphine $7.5 \mathrm{mg} / \mathrm{kg}$ bw, latency increases and stands at 8.13 $\pm 0.66 \mathrm{~s}$ and at $10 \mathrm{mg} / \mathrm{kg}$ bw, the animal no longer withdraw more, its tail of the heating light beam.

Table 1: Effects of Morphine and the Aqueous Extract of Ximenia Americana on the Withdrawal Latency of the Rat's Tail from the Path of the Light Beam Heating.

\begin{tabular}{|c|c|c|}
\hline Group & $\begin{array}{l}\text { Latency of the tail withdrawal } \\
\text { (s) }\end{array}$ & $\begin{array}{l}\text { Increased latency } \\
(\%)\end{array}$ \\
\hline Control & $5,95 \pm 0,54$ & - \\
\hline $\begin{array}{l}\text { Morphine } \\
7,5 \mathrm{mg} / \mathrm{kg} \text { bw }\end{array}$ & $8,13 \pm 0,66^{*}$ & $33,60 \pm 3,5$ \\
\hline $10 \mathrm{mg} / \mathrm{kg}$ bw & $12,44 \pm 0,19 * * *$ & $100 \pm 1,5$ \\
\hline $\begin{array}{l}\text { Ximenia ameri- } \\
\text { cana } \\
100 \mathrm{mg} / \mathrm{kg} \mathrm{bw}\end{array}$ & $6,12 \pm 0,36$ & $2,61 \pm 0,9$ \\
\hline
\end{tabular}

Values represent the mean $\pm \mathrm{SEM} ; \mathrm{n}=6$ for each group. $* \mathrm{P}$ $<0.05$; ** $\mathrm{P}<0.01$; *** $\mathrm{P}<0.001$ compared to the control group.

The aqueous extract from Ximenia americana, unlike morphine, had no effect on the latency of withdrawal of the rat's tail.

\subsection{Formaldehyde test}

Figure 2 shows the intensity of pain in rats after injection of the formaldehyde in the absence and presence of phenylbutazone, aqueous extract of Ximenia americana and its fractions.

After injection of $2.5 \%$ formaldehyde to lot of control rats, we record a painful intensity of $2.8 \pm 0.1$ during the first phase and of $2.7 \pm 0.2$ during the second phase $(n=6)$.

In the presence of $100 \mathrm{mg} / \mathrm{kg}$ bw of phenylbutazone, Ximenia americana and its fractions F1 to F6, the intensity of the pain does not vary during the 1 st phase, it is equal to $2.8 \pm 0,1$. On the other side, it significantly decreased $(\mathrm{p}<0.05)$ during the second phase. The percentage of inhibitory effects of Ximenia americana dosed at $100 \mathrm{mg} / \mathrm{kg}$ of bw equal to $75 \pm 4 \%$ are similar to those of $\mathrm{F} 1$, F4 and F6 at the same dose. The inhibitions induced by these three fractions are respectively equal to $75.3 \pm 3 \% ; 79.2 \pm 4 \%$ and 83.3 $\pm 4 \%$, compared to the control (Figure 2).

These effects are much greater than those caused by phenylbutazone, and fractions F2, F3 and F5 tested at the same dose. The inhibitions induced by these four substances are respectively equal to $58.3 \pm 4 \% ; 16.66 \pm 2 \% ; 16.66 \pm 3 \%$ and $16.66 \pm 3 \%$.
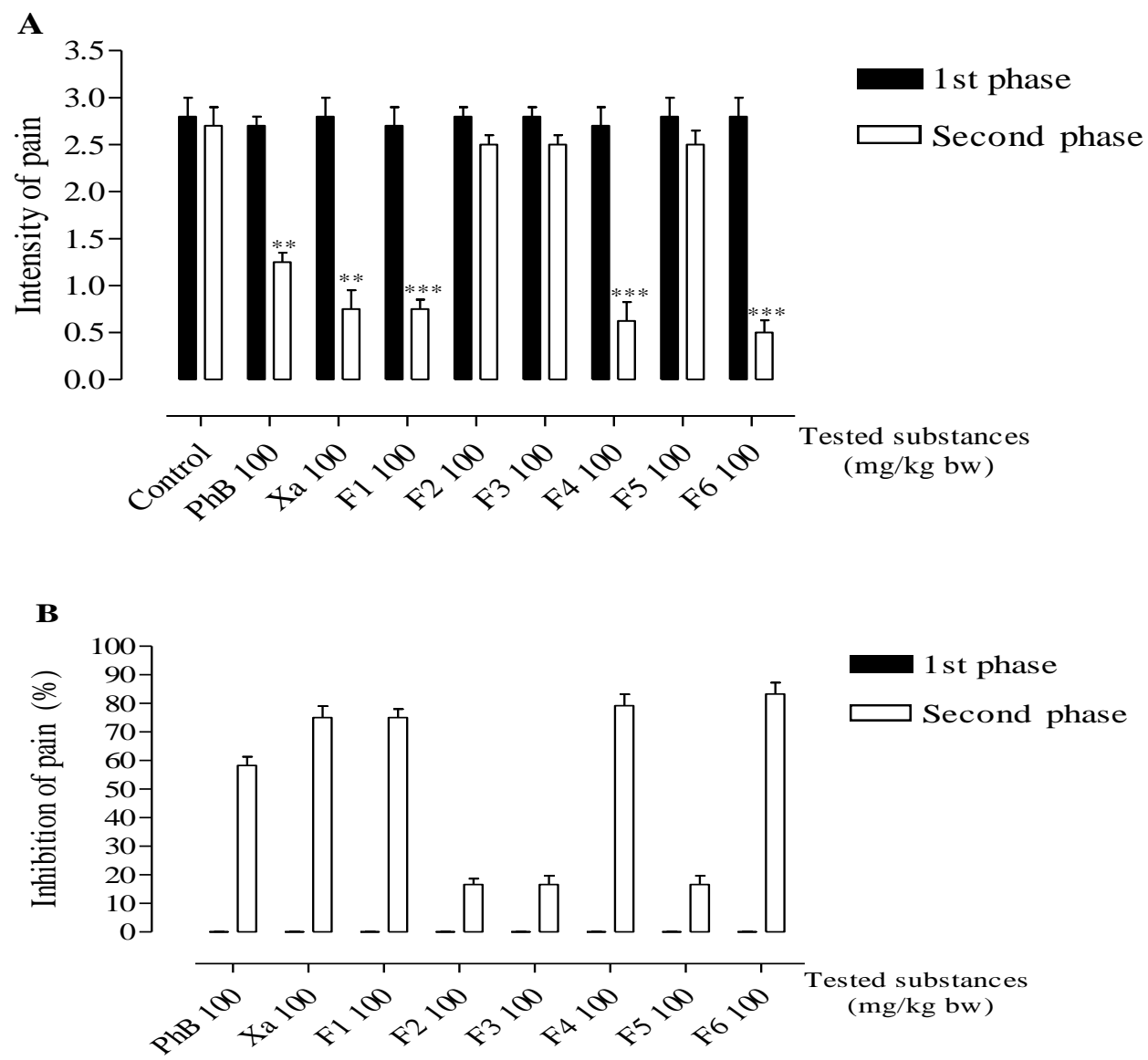

Fig. 2: Comparative Study of the Effects of Phenylbutazone, of the Aqueous Extract of Ximenia Americana and Its Fractions on Pain Intensity Formaldehyde-Induced in Rat.

A: Pain intensity after injection of formaldehyde in the absence and presence of phenylbutazone, aqueous extract Ximenia americana, and its various fractions.

Ximenia americana has an inhibitory effect on pain greater than that of phenylbutazone. This effect is similar to that of fractions F1, F4 and F6

$\mathrm{B}$ : Percent inhibition of pain in the rat after injection of formaldehyde in the presence of phenylbutazone, aqueous extract of Ximenia americana and its fractions.

Ximenia americana and its fractions F1, F4 and F6 have inhibition percentages of pain similar.

Values represent the mean \pm SEM; $\mathrm{n}=6$ for each group $* \mathrm{p}<0.05 ; * * \mathrm{p}<0.01 ; * * * \mathrm{p}<0.001$ compared to the control group. 


\section{Discussion}

The aqueous extract of Ximenia americana administered at a dose of $100 \mathrm{mg} / \mathrm{kg}$ body weight as the fractions F1, F4 and F6, inhibit abdominal cramps caused by the injection of the acetic acid in the writhing test. These results indicate that Ximenia americana and its fractions F1, F4 and F6 have analgesic effects.

These analgesic effects are similar to those of phenylbutazone. In fact, $100 \mathrm{mg} / \mathrm{kg} \mathrm{bw}$, phenylbutazone causes pain inhibition of $45.2 \pm 2 \%$. In the presence of the aqueous extract of Ximenia americana and its fractions F1, F4 and F6, the percentage of inhibition recorded, is $61.1 \pm 2 \% ; 62.5 \pm 2 \% ; 69.3$ and $65.4 \pm 2 \% \pm$ $2 \%$ for the same concentration.

The morphine, a central analgesic administered at the dose of 10 $\mathrm{mg} / \mathrm{kg}$ bw, inhibits the effect of the pain induced by heat focused on the rat's tail. The aqueous extract from Ximenia americana administered at a concentration of $100 \mathrm{mg} / \mathrm{kg}$ body weight has no effect on this pain. Accordingly the aqueous extract of Ximenia americana has, essentially peripheral analgesic action. It is indeed known that the thermal stimuli are selectively inhibited by central analgesics and not by peripheral analgesics (Chang \& Lewis 1989, Sayyah et al. 2004).

Ximenia americana has a peripheral analgesic action similar to that of Diospyros variegata (Trongsakul et al. 2003).

To confirm the above results we performed a comparative study of the effects of phenylbutazone, of the extract of Ximenia americana and its fractions on pain induced by formaldehyde. Unlike central analgesics such as morphine that inhibit both phases of the formaldehyde test (Tjolsen et al. 1992, Shibata et al. 1989, Vasudevan et al. 2007). Ximenia americana and its fractions F1, F4 and F6 have significant inhibitory effects only on the second phase of the pain induced by this reference molecule. Ximenia americana and its fractions F1, F4 and F6 would be the peripheral analgesics. Therefore, these naturally occurring substances would have the same action mechanism as aspirin, phenylbutazone and indomethacin that are peripheral analgesic.

These substances as well as Ximenia americana and its fractions F1, F4 and F6 inhibit the inflammatory phenomena caused by formaldehyde in the second painful phase (Rosland et al. 1990, Young et al. 2005, Nguemfoa et al. 2007, Youmbie et al. 2015). The fractions F1, F4 and F6 of Ximenia americana have greater analgesic properties than the fractions F2, F3 and F5 because they are definitely more rich in flavonoids and saponins (Alaoui et al. 1998, Nasrin et al. 2015) which are inhibitors of prostaglandins. Deraedt et al. (Deraedt et al. 1980) showed high proportions of prostaglandin PGE2 $\alpha$ and PGF2a in the peritoneal exudate of rats after injection of acetic acid and Hokanson (1978); Duarte et al. (1978); and Neto et al. (2005) have meanwhile them observed in the same conditions, the release of mediators of the sympathetic nervous system. The effects of the aqueous extract of Ximenia americana and its fractions F1, F4 and F6 may be related to the inhibition of lipo-oxygenase and / or cyclooxygenase.Trongsakul et al. (2003), Gupta et al. (2005). Indeed the inhibition of these enzymes according to Griswold et al. (1990), Mylari et al. (1991), Rioja et al. (2002), Ojewole, (2007), Rajkumar \& Sellamuthu (2015), causes a reduction in peripheral pain.

\section{Conclusion}

The aqueous extract of Ximenia americana and its fractions F1, F4 and F6 would be the peripheral analgesics rich in flavonoids and saponins, these natural substances, would inhibit the prostaglandins. Their effects could be related to the inhibition of lipooxygenase and / or cyclooxygenase.

\section{References}

[1] Alaoui K, Lagorce J F, Cherrah Y, Hassar M, Amarouch H \& Roquebert J (1998) Activité analgésique et anti-inflammatoire des saponines d'Argania spinosa, in : Annales pharmaceutiques françaises, pp. 220-228.

[2] Boullard B (2001) Plantes médicinales du Monde. Croyances et réalités. Editions ESTEM,pp. 565-566.

[3] Chang J Y \& Lewis A J (1989) Pharmacological methods in the control of inflammation. Modern Methods in Pharmacology 5, 195212.

[4] Collier H O J, Dinneen L C, Johnson C A \& Schneider C (1968) The abdominal contraction response and its suppression by antinociceptive drugs in the mouse. British J. Pharmacol. Chemother 32 295-310.http://dx.doi.org/10.1111/j.1476-5381.1968.tb00973.x.

[5] D'Amour F E \& Smith D L (1941) A method for determining loss of pain sensation. J. Pharmacol. Exp. Ther 72, 74-79.

[6] Deraedt R, Jougney S, Benzoni J \& Peterfalvi M (1980) Release of prostaglandins $\mathrm{E}$ and $\mathrm{F}$ in algogenic reaction and its inhibition. Eur. J. Pharmacol61, 17-24.http://dx.doi.org/10.1016/00142999(80)90377-5.

[7] Duarte J D G, Nakamura M \& Ferreira S H (1988) Participation of the sympathetic system in acetic acid induced writhing in mice. Brazil.J. Med. Biol. Res 21, 341-343.

[8] Dubuisson D \& Dennis S G (1977) The formalin test: A quantitative study of the analgesic effect of morphine, meperidine, and brainstem stimulation in rats and cats. Pain 4, 161174.http://dx.doi.org/10.1016/0304-3959(77)90130-0.

[9] Gray W D, Osterberg A C \& Scute J T (1970) Measurement of the analgesic efficacy and potency of pentazocine by the D'Amour and Smith method. J. Pharmacol. Exp. Ther 172, 154-162.

[10] Griswold D E, Marshall P, Martin L, Webb E F \& ZabkoPotapovich B (1991) Analgesic activity of SK \& F 105809, a dual inhibitor of arachidonic acid metabolism. Agents and Actions 32, 113-117.

[11] Gupta M, Mazumder U K, Sambath Kumar R, Gomathi P, Rajeshwar Y, Kakoti B B \& Tamil Selven V (2005) Antiinflammatory, analgesic and antipyretic effects of methanol extract from Bauhinia racemosa stem bark in animal models. J. Ethnopharmaco 98 ,

267 273.http://dx.doi.org/10.1016/i.jep.2005.01.018.

[12] Hokanson G C(1978)Acetic acid for analgesic screening. J. Nat Prod 41, 497-498.

[13] Kerharo J \&Adam JC(1974) La pharmacopée sénégalaise traditionnelle. Plantes médicinale et toxiques. Ed. Vigot-Frères, Paris.

[14] Koster R, Anderson M \& De Beer J (1959) Acetic acid for analgesic screening. Federal Proceeding 8, 412- 417.

[15] Mylari B L, Carty T J, Moore P F \& Zembrowski W J (1990) 1,2Dihydro-1-oxopyrrolo [3,2,1-kl] phenothiazine-2-carboxamides and congeners, dual cyclooxygenase/5-lipoxygenase inhibitors with anti-inflammatory activity. J. Med. Chem 33, 2019 2024.http://dx.doi.org/10.1021/jm00169a035.

[16] Nasrin F, Hakim Md L, Pinon R M, Chakraborty M, Sarker N G \& Alam K (2015) Analgesic study of methanolic extracts of loranthus europaeus leaf and stem. World journal of pharmacy and pharmaceutical sciences Volume 4, Issue 07, 11-19.

[17] Neto A G, Costa J M L C, Belati C C, Vinholis A H C, Possebom L S, Da Silva Filho A A, Cunha W R, Carvalho J C T, Bastos J K \& Silva M L A E (2005)Analgesic and anti-inflammatory activity of a crude root extract of Pfaffia glomerata (Spreng) Pedersen. J. Ethnopharmaco196, 87-91.http://dx.doi.org/10.1016/j.jep.2004.08.035.

[18] Nguemfoa E L,Dimoa T, Azebaze A G B, Asongalem E A, Alaoui K, Dongmoe A B, Cherrah Y \& Kamtchouing P (2007) Antiinflammatory and anti-nociceptive activities of the stem bark extracts from Allanblackia monticola STANER L.C. (Guttiferae). J. Ethnopharmacol. 114 , 424.http://dx.doi.org/10.1016/j.jep.2007.08.022.

[19] Ojewole J A O (2007) Analgesic, anti-inflammatory and hypoglycemic effects of Rhus chirindensis (Baker F.) [Anacardiaceae] stem-bark aqueous extract in mice and rats. J. Ethnopharmacol 113, 338-345.http://dx.doi.org/10.1016/j.jep.2007.06.025.

[20] Rajkumar G \& Sellamuthu M, (2015) Analgesic and acetylcholinesterase inhibition potential of polyphenols from Scolopia crenata (Flacourtiaceae): An endemic medicinal plant of India. Industrial Crops and Products 73, 134143http://dx.doi.org/10.1016/j.indcrop.2015.03.090

[21] Rioja I, Terenci M C, Ubeda A, Molina P, Tarraga A, GonzalezTejero A \& Alcaraz M J (2002) A pyrroloquinazoline derivative 
with anti-inflammatory and analgesic activity by dual inhibition of cyclo-oxygenase-2 and 5-lipoxygenase. Eur. J. Pharmacol 434 177-185.http://dx.doi.org/10.1016/S0014-2999(01)01539-4.

[22] Rosland J H, Tjolsen A, Maehle B \& Hole K (1990) The formalin test in mice: Effect of formalin concentration. Pain 42, 235 242.http://dx.doi.org/10.1016/0304-3959(90)91167-H.

[23] Sayyah M A, Hadidi N B \& Kamalinejad M B (2004) Analgesic and anti-inflammatory activity of Lactuca sativa seed extract in rats. J. Ethnopharmacol 92, 325329.http://dx.doi.org/10.1016/j.jep.2004.03.016.

[24] Shibata M, Ohkubo T, Takahashi H \& Inoki R (1989) Modified formalin test: characteristic biphasic pain response. Pain 38, 347352.http://dx.doi.org/10.1016/0304-3959(89)90222-4.

[25] Soro T Y, Traore F \& Sakande J (2009) Activité analgésique de l'extrait aqueux de Ximenia americana (Linné) (Olacaceae). C. R. Biologies 332, 371377.http://dx.doi.org/10.1016/j.crvi.2008.08.022.

[26] Tjolsen A, Berge O G, Hunskaar S, Rosland J H \& Hole K (1992) The formalin test: an evaluation of the method. Pain 51, 517.http://dx.doi.org/10.1016/0304-3959(92)90003-T.

[27] Trongsakul S, Panthong A, Kanjanapothi D \& Taesotikul T (2003) the analgesic, antipyretic and anti-inflammatory activity of Diospyros variegata Kruz. J. Ethnopharmacol 85, 221225.http://dx.doi.org/10.1016/S0378-8741(03)00020-5

[28] Trongsakul S, Panthong A, Kanjanapothi D, \& Taesotikul T (2003) the analgesic, antipyretic and anti-inflammatory activity of Diospyros variegata Kruz. J. Ethnopharmacol. 85, 221225.http://dx.doi.org/10.1016/S0378-8741(03)00020-5.

[29] Vasudevan M, Gunnam K K \& Parle M (2007) Anti nociceptive and anti-inflammatory effects of Thespesia populnea bark extract. J. Ethnopharmacol 109 270.http://dx.doi.org/10.1016/j.jep.2006.07.025.

[30] Wagner H (1983) Drogen analyse, dünschicht chromatographische analyse von arzneidrogen. Springer Verlag Berlin heidelberg, New York.

[31] Youmbie D D B, Dzeufiet D P D, Nkwengoua E, Mezui C \& Dimo $\mathrm{T}$ (2015) Anti-inflammatory and anti-nociceptive effects of the stem bark aqueous extract of rauwolfia vomitoria (apocynaceae). World journal of pharmacy and pharmaceutical sciences, Volume 4, Issue 07, 90-112.

[32] Young $\mathrm{H}$, Luo $\mathrm{Y}$, Cheng $\mathrm{H}$, Hsieh W, Liao J \& Peng W (2005)Analgesic and anti-inflammatory activities of [6]-gingerol. J. Ethnopharmacol 96 ,

$207-$ 210.http://dx.doi.org/10.1016/j.jep.2004.09.009.

[33] Zirihi G N (2006) Etudes botanique, pharmacologique et phytochimique de quelques plantes médicinales anti-paludiques et/ou immunogènes utilisées chez les Bété du département d'issia, dans l'ouest de la Côte d'Ivoire, Thèse de Doctorat d'Etat ès science, Université Abidjan - Cocody. 